CZU:821.135.1.09(478)(092)

https://doi.org/10.52505/lecturi.2021.05.26

\title{
TUDOR PALLADI LA 75 ANI - PORTRET ENCICLOPEDIC
}

\author{
Dan VEREJANU \\ Institutul de Filologie Română „Bogdan Petriceicu-Hasdeu”, Chișinău
}

Rezumat. Poet, traducător, eseist, critic și istoric literar, editor, Tudor Palladi, pe parcursul anilor de maturitate profesionistă, trece la o poezie metafizică umanistă, concentrat asupra puterii transformatoare a imaginației, preocupările sale imaginare find dintotdeauna luminoase şi reflexive. Iubirea eternă e evadarea metafizică a poetului Tudor Palladi. Prin poezie autorul lș̣i recuperează destinul. Registrul meditației sale are mari profunzimi sufletești, deține puterea de a conecta misterul sufletesc cu misterul cosmosului, a universului infinit, cu Puterea Divină.

Cuvinte-cheie: imaginație, poezie metafizică, metaforă, meditație, mister, redactor, antologator, acrostih, rondel, dedicații, „steligrame”, ,pălăduiri”, „arheii”.

Abstract. Poet, translator, essayist, historian and literary critic, editor, Tudor Palladi during the period of his professional maturity has passed from a poetry humanitarian and metaphysical, focused on the transformative power of imagination, to his imaginary preoccupations, always enlightened and reflexive. The metaphysical escape of the poet is eternal love; through poetry the author regains his destiny. The meditation registry has great spiritual depths and has the power to connect the spiritual mystery with the Cosmos, the infinite universe, the divine power.

Keywords: imagination, metaphysical poetry, metaphor, meditation, mystery, editor, dedications.

Poet, traducător, eseist, critic și istoric literar, editor Tudor Palladi s-a născut la 6 iunie 1946, în familia Eufrosiniei Lupu și Ion Paladi din Bălănești, Nisporeni. După absolvirea celor 11 ani la școala medie în localitatea de baştină, în 1964 devine student la Facultatea de Filologie a Universităţii de Stat din Moldova. În 1969 susține examenele de stat și obține diploma de specialist-filolog. După cum erau timpurile de pe atunci - face, în mod obligatoriu, și doi ani de armată. Începând cu 1972 practică o imensă muncă de redactor literar, dedicându-se viața toată. A activat la editurile chișinăuiene, precum ar fi: Cartea Moldovenească (actualmente Cartea Moldovei), Literatura Artistică, Hyperion, Litera, Lumina, Pontos etc. Împreună cu criticul și istoricul literar Ion Ciocanu, a coordonat în 1996 elaborarea și completarea Colecției Biblioteca școlarului la Editura Litera.

Debutul literar prin poezie îl face în 1974 în paginile ziarului Tinerimea Moldovei. Peste un an, cu articolul „Poetul pasiunii etice” (despre poezia lui 
Gheorghe Vodă) debutează în calitate de critic literar în Revista „Nistru”; cu volumul de poezii Plăpând ca un colte (1990) face debutul editorial. E autorul cărților Mugurașii mugurei, 1991, Odiseea lacrimii, 1994, Un secol de literatură română (4 volume), Editura Lumina 2005, Momentul monumentelor perene (studii critice), 2005. Apogeul carierei literare îl constituie ultimul deceniu sec. XXI - (2011-2021), când poetul și criticul literar va lansa unul după altul zeci de volume de critică și istorie literară, de poezii pentru adulți și copii: 101 poeme, 2011, Nemărginirea clipei, 2011, Semință și altar, 2012, Talismanul ursitei, 2012, Creatorul de risipă, 2013, Arheu, 2013, Unul în trei, 2014, Apoteoză, 2014, Cenuşa din suspine, 2014, Rămurașii-rămurei, 2014, Pomurașii-Pomurei, 2014, Edena cea eternă, 2015, Unul în patru: poeme (Pălăduiri), 2017, Aisbergul inimii, 2018 ș.a. Cărți de critică și istorie literară: Reconfigurarea unui fenomen literar artistic insolit, 2017, Metafora între cuvânt și dramă, (trilogie), 2012, 2017, 2020. Pe parcursul acestor ani de maturitate profesionistă, poetul scrie poezie metafizică umanistă, concentrat asupra puterii transformatoare a imaginației, preocupările sale fiind dintotdeauna luminoase şi reflexive. Iubirea eternă e evadarea metafizică a poetului Tudor Palladi; prin poezie autorul își recuperează destinul. Registrul meditaţiei sale are mari profunzimi sufletești, care deține puterea de-a conecta misterul sufletesc cu misterul cosmosului, a universului infinit, cu Puterea Divină.

Admiratorul de singurătate, Tudor Palladi, adolescentul, se refugia în vârful dealului pe care este așezat satul de baștină, visându-și destinul. Apoi, poetul Tudor Palladi, se refugia în meditaţiile sale, în cele mai tainice dialoguri imaginare cu cosmosul, cu Puterea Divină, cu viitorul. Pe cât de ,uitat”, ca poet, pe atât de necesar în calitate de critic literar, uneori chiar rugat să umple pagina în cuvinte cu pondere despre un condeier care trebuia să obțină calitatea de membru al USM sau pentru aniversarea altui poet deja consacrat, scriitorul Tudor Palladi e unul dintre foarte puţinii care a lecturat opera tuturor colegilor săi. A studiat ca nimeni altul operele scriitorilor contemporani, le-a citit și analizat creația, l-a prețuit pe fiecare după ce avea mai bun. Semnează numeroase eseuri și cronici literare în presa din Republica Moldova, dar și din România despre creația scriitorilor: Andrei Lupan, Emilian Bucov, Vitalie Tulnic, Anatol Gugel, Vasile Levițchi, Agnesa Roșca, Igor Crețu, Gheorghe Vodă, Mircea Lutic, Arhip Cibotaru, Ion Gheorghiță, Paul Mihnea, Lidia Istrati, Mihail I. Cibotaru, Nicolae Esinencu, Nicolae Mătcaș, Ion Diordiev, Serafim Belicov, Boris Schițco, Lidia Ungureanu, Iulian Cârchelan, Vasile Căpățână, Ion Proca, Marcela Benea, Ion T. Zegrea, Ion Anton, Nina Slutu, Nina Josu, Ion Cațaveică, Anatol Rău ș.a. A fost impresionat de opera și destinul tragic al tinerei poete Steliana Grama, cărei i-a dedicat mai multe volume de poezii.

Tudor Palladi are un bogat palmares în calitate de antologator, bibliograf, scriind prefață sau postfață la numeroase volume, studii în monografii și enciclopedii: Darul ceresc al bunătății sau Druță după Druță în „Fenomenul artistic Ion Druță”, 2008; „Ostatecul” ,, Salcâmului din prag” și-al „Părții noastre de zbor”, în „Metafora între cuvânt și dramă”, vol. III, (Liviu Damian la 60 de ani); 
Scrieri alese de Lidia Istrati, 2014; Grigore Vieru „,um şi în veac” (80 de ani de la nașterea poetului); Maestru și Salahor (Ion Ciocanu: Unul în trei), Ion Ciocanu la 80 ani; Principialitatea estetică a bunului-simţ (criticul literar Andrei Țurcanu la 50 de ani); „Ofranda celestă a poeziei sau magia revelației” (prefață la Opere Alese de Renata Verejanu, în 12 vol., 2015); „Imanența refugiului metafizic sau coroana destinului orfic” (Leonida Lari la 50 ani), 1999; An. Codru „Opere alese”; Vlad Zbârciog, Opere alese; „Intre aspirație și inspirație” (Eufemia Țopa: Un contur de poet decaetic) 2011; Galina Furdui. Spațiu interactiv pentru nucleu (dialoguri, interviuri), Chișinău, 2013; „Cântecul cu o mie de cuvinte” prefață - Irina Stavschi (la 100 ani), 2019; Parodia poeziei şi poezia parodiei sau Ironia între persiflare şi diversificare: (portret de creaţie al poetului Titus Ştirbu); Spectacolul sau misterul nesfârşit al eulogiei (despre creația lui Anatol Ciocanu).

Munca criticului și istoricului literar Tudor Palladi se încununează cu mai multe volume de sinteză, printre care și cele trei volume cu același nume dar conținut diferit, Metafora între cuvânt și dramă, Chișinău, Editura Lumina. Primul volum (2012), cuprinde peste 20 de nume de scriitori, de la Alexie Mateevici până la Andrei Ciurunga, George Meniuc, Nicolae Costenco, Magda Isanos, Petru Zadnipru, Ion Druță, Aureliu Busuioc. În volumul doi (editat în 2017) sunt reuniţi șaizeciștii: Victor Teleucă, Liviu Damian, Grigore Vieru, Ion Vatamanu, Dumitru Matcovschi, Emil Loteanu, Pavel Boțu, Petru Cărare, Anatol Ciocanu. Cel de-al treilea volum al trilogiei Metafora între cuvânt și dramă (2020) e dedicat celor peste cincizeci de nume a șaptezeciștilor: de la poetul bucovinean Vasile Tărâțeanu la Efim Tarlapan, Vasile Romanciuc, Renata Verejanu, Ion Hadârcă, Arcadie Suceveanu, Iulian Filip, Galina Furdui, Marcela Mardare, Constantin Dragomir, Leonida Lari, Alexe Rău, Leonard Tuchilatu.

Parcurgându-și drumul său în căutarea unui rost, poetul T. Palladi, șaptezecist prin chipul poetic al liricii sale, a continuat traiectoria poeților metaforici, cursiv și senin în stilul majorității poemelor de rezistență prin timp. Bucurându-se că e lăsat în pace de lauda locală, Tudor Palladi - „o instituție aparte”, cum 1-a numit Ion Druță, și-a scris opera poetică provocat cumva de lirica câtorva poete de la Chișinău, pe care le-a apreciat, adunând toate poeziile dedicate femeii în trei volume de poezie cu dedicație specială: Stelianei Grama. Volumele de poeme Cenuşa din suspine (2014), Edena cea eternă (2015), Unul în patru: (Pălăduiri) 2017, rămase neobservate de critica literară la prima lor apariție editorială, unite în volumul antologic Aisbergul iubirii atrag îndată atenția exegeților. Criticul literar Ion Ciocanu scrie prefață, Elena Țau, Victoria Fonari, Mariana Jioară îmbogățesc postfaţa volumului cu studii importante. Unic prin volumul Aisbergul inimii, T. Palladi își începe discursul liric cu dedicații mai multor oameni de cultură, personalități din diferite domenii pe care i-a cunoscut, plecați în nemurire, și continuă cu peste 600 pagini de poezie dedicate regretatei Steliana Grama.

Acest fenomen a fost observat și apreciat de criticul literar Ion Ciocanu, în „Metafizica iubirii: Steliana Grama ca sursă de inspirație lirică”: „Tudor Palladi 
ne-a dat aceste ... cărți profund simțite, bine gândite arhitectural, original realizate, spre bucuria oricărui prețuitor sincer și dezinteresat al poeziei autorului, principial deosebite de tot restul poeziei basarabene actuale," lăsând să se înțeleagă că dincolo „de metafizica iubirii cititorul are a descifra un noian de imagini și gânduri, sentimente” și că volumul necesită o citire și analiză profundă. „Noutatea volumului cinstește specia acrostihului îmbinată cu cea a rondelului (pe care autorul le mai numește segeuri şi steligrame)", afirmă exegetul, referindu-se la volumul „Aisbergul inimii” (Ciocanu, 2018, p. 11).

În eseul „Poezia rugii stelare sau ,, aisbergul” criptoerotic al ,,inimii”, dr. Victoria Fonari constată că în „Cenușa din suspine” motoul din textele Stelianei Grama sunt așchiile dialogului poetic. Deși într-un dialog e obligatorie prezența unui eu și tu concomitent, în spațiul artistic atestăm o comunicare dintre versuri. Motoul din versul poetei apare ca o acordare de strună a instrumentului muzical ales în „pălăduiri” (Fonari, 2018, p. 854). Revenind la „pălăduiri”, V. Fonari specifică , în cazul textului artistic este protecția de anxietate, dezvăluirea durerii și a iubirii, a fortificării cuvântului întru creație, perceput drept o conexiune dintre lumea reală și cea a ideilor, cuvântul cu esența armonie întru prosperarea spiritualului" (Fonari, 2018, p. 857).

Aceste steligrame (de la Steliana Grama) ca și pălăduirile (de la Palladi), cuvinte create de poet, sunt metafore astrale, telegrame spre cosmos, spre poeții plecați în nemurire. Fiind ademenit de „,Miracolul miracolelor toate”, ocrotit și îndrumat de „Poetul cel mai mare - Dumnezeu”, autorul ,,Veghează-n lacrimi Pomii ce-nfloresc”, deoarece "Metafora ca floarea e-un produs /Al Firii pentru care-un Cer lucrează", afirmă Tudor Palladi în volumul de poeme Arheu. Vorbind de arheii poetului în studiul „Arheii și emblematica lor în poezia lui Tudor Palladi”, cercetătoarea Elena Țau a observat că „rădăcinile cuvintelor sunt cerești”. Poetul „, evocă un cuplu arhetipal de îndrăgostiți, în care recunoaștem, grație referințelor, persoane concrete (mai exact, pe sine însuși și pe regretata poetă Steliana Grama") (Țau, 2018, p. 847). Cercetătoarea constată că „Edificați în principal pe temelii arhetipale, arheii lui mai realizați... se desemnează frecvent cu ajutorul simbolului și metaforei drept embleme polivalente ale unor esențe, principii și valori netrecătoare” (Țau, 2018, p. 849). Volumele „Cenuşa din suspine”, „Edena cea eternă”, ,,Unul în patru”, adunate în antologia Aisbergul iubirii, pot fi apreciate ca un îndemn să întreținem nemurirea Stelianei Grama. Această valorificare a gândirii regretatei poete îi face cinste și onoare poetului Tudor Palladi.

Despre opera şi activitatea lui Tudor Palladi au scris oameni de cultură din republică și din România: acad. Mihai Cimpoi (Noblețea modestiei), dr. hab. Ion Ciocanu, (mai multe studii, referințe), dr. hab. Mihail Dolgan (Iubire de metaforă), Florin Popescu (Basarabia, locul unde patriotismul se trăiește mai intens), Mariana Jioară (Un dor instelat de iubire), Elena Manea-Cernei ( $O$ columnă de vise şi stele sau ancorarea în lumina cuvântului), dr. Elena Țau, Elena Țarălungă, dr. Victoria Fonari, Vlad Zbârciog, Gheorghe Vodă, Victor Teleucă. 
În calitate de traducător a oferit tălmăciri în limba română din creația poeților ruși, găgăuzi din Moldova, precum și din literatura universală. Tudor Palladi a dăruit cititorilor peste 20 de cărți de poezii pline de „cuvinte-flori” și „flori-cuvinte", de istorie literară, de traduceri. Activitatea poetului a fost apreciată pe parcursul anilor cu diferite premii: Premiul „Centenarul Marii Uniri” (2018), Premiul „Opera Omnia” (2019), Premiul „Vasile Coroban” (2020), Premiul „Mihai Cimpoi” (2021) - toate oferite de Uniunea Internațională a Oamenilor de Creație la Gala Premiilor. Este membru al Uniunii Scriitorilor din Moldova (1991) și membru al Uniunii Internaționale a Oamenilor de Creație (din 2018). Acum, la împlinirea celor 75 de ani, încununaţi de o valoroasă contribuție literară și o activitate bogată consacrată valorificării creației generațiilor de intelectuali basarabeni, - colegii, prietenii și tinerii condeieri îi urează Omului de litere Tudor Palladi din toată inima „La mulți ani!”.

SCRIERI: Plăpând ca un colte, Chișinău,1990, Mugurașii mugurei, Chișinău,1991, Odiseea lacrimii, Chișinău, 1994, 101 poeme, București, 2011, Nemărginirea clipei, Chișinău, 2011, Semință și altar, Chișinău, 2012, Talismanul ursitei, Chișinău, 2012, Creatorul de risipă, Iași, 2013, Arheu, Iași, 2013, Unul in trei, Chișinău, 2014, Apoteoză, Iași, 2014, Cenuşa din suspine, Chișinău, 2014, Rămurașii-rămurei, Chișinău, 2014, Pomuraşii-Pomurei, Chișinău, 2014, Edena cea eternă, Chișinău, 2015, Unul în patru: poeme (Pălăduiri), Chișinău, 2017, Aisbergul inimii, Iași, 2018 ș.a. Cărți de critică și istorie literară: Un secol de literatură română, ed.Lumina (4 volume), Chișinău, 2005, Momentul monumentelor perene (studii critice în 4 volume), Chișinău, 2005, „Împlinirea în Suferință” sau Epifaniarea ideii și sentimentului de OM, București, 2016, Reconfigurarea unui fenomen literar artistic insolit, Chișinău, 2017, Aisbergul inimii. /poeme, pălăduiri/ ed. TipoMoldova, Iaşi, 2018, Metafora între cuvânt și dramă, v.1, Chișinău, 2012, Metafora între cuvânt și dramă, v.2, Chișinău, 2017, Metafora între cuvânt și dramă, v.3. Chișinău, 2020.

\section{Referințe bibliografice:}

1. CIOCANU, Ion. Metafizica iubirii: Steliana Grama ca sursă de inspirație lirică. În „Tudor Palladi. Aisbergul inimii”, p. 5-11, Iași: TipoMoldova, 2018.

2. FONARI, Victoria. Poezia rugii stelare sau ,aisbergul” criptoerotic al „inimii”. În „Tudor Palladi. Aisbergul inimii”, p. 850-866, Iași: TipoMoldova, 2018.

3. ȚAU, Elena. Arheii și emblematica lor în poezia lui Tudor Palladi. În „Tudor Palladi. Aisbergul inimii”, p. 841-849, Iași, TipoMoldova, 2018.

Notă: Articolul a fost realizat în cadrul proiectului de cercetare 20.80009.1606.03 Contexte socioculturale autohtone şi interconexiuni europene în creaţia populară şi literatura cultă din Basarabia (sec. XIX până în prezent), Institutul de Filologie Română «B. P.-Hasdeu” al MEC. 